\title{
Late-18th- and Early-19th-Century Inuit and Europeans in Southern Labrador RÉGINALD AUGER ${ }^{1}$
}

(Received 3 December 1990; accepted in revised form 31 August 1992)

\begin{abstract}
The Inuit presence, except at Red Bay, is not archaeologically visible until the end of the 18th century, despite the written accounts that document their presence in the Strait of Belle Isle from as early as the 16th century. It appears that they were attracted by the increased European fishing activities in the area. The European presence consisted of fishermen (planter fishermen) posted at the best fishing locations in the Strait of Belle Isle. They adopted a housing style borrowed from the Labrador Inuit, and that trait is notable for the period between the last decade of the 18 th century into the middle of the 19th century.

The similarities observed between the two ethnic groups demonstrate how complex it is to differentiate them, as a result of cross-acculturation. The Inuit living in close proximity to European stations replaced their traditional material culture with European-made goods in a very short time period, while the European settlers were building sod houses identical to what we know of the 19th-century Labrador Inuit.

Key words: Strait of Belle Isle, Labrador Inuit, Europeans, acculturation, historical archaeology, sod houses, 18th-19th century

RÉSUMÉ. Contrairement à ce que nous apprenons des sources écrites qui nous suggèrent que les Inuit du Labrador fréquentaient le détroit de Belle Isle à une période aussi ancienne que le 16ième siècle, les résultats de recherches archéologiques démontrent qu'à l'exception des restes trouvés à Red Bay, leur présence n'est attestée qu'à la fin du 18ième siècle. Il appert que leur présence aurait découlé d'une attraction accrue suscitée par les activités de pếche des Européens. La présence européenne est attribuée à des groupes de pêcheurs stationnés aux lieux de pêche les plus productifs du détroit. Ces pêcheurs (planter fishermen) dont les évidences sont identifiés entre la dernière décennie du 18ième siècle jusqu'au milieu du 19ième siècle ont adopté un style d'habitation emprunté aux Inuit du Labrador.

Les emprunts culturels observés entre ces deux groupes ethniques démontrent un niveau d'acculturation à un point tel qu'il est extrêmement difficile de les distinguer. Les Inuit vivant à proximité des stations de pêche ont très rapidement troqué leur culture matérielle traditionelle pour des objets de traite européens alors que les Européens ont construit des habitations en tourbe identiques aux habitations que nous connaissons chez les Inuit du Labrador au $19 i e ̀ m e$ siècle.
\end{abstract}

Mots clés: Détroit de Belle Isle, Inuit du Labrador, Européens, acculturation, archéologie historique, maisons de tourbe, 18-19 siècles

\section{INTRODUCTION}

The results of the research presented here stemmed initially from a debate over the interpretation of documents related to the presence of the Labrador Inuit in southern Labrador (Martijn and Clermont, 1980a,b). Specifically, the argument had to do with whether or not Inuit frequented the Strait of Belle Isle as early as the 16th century, or if Inuit had only begun to settle the strait at the end of the 18th century. Using primary sources such as the archival documents cited in Martijn and Clermont (1980a), Martijn (1980a,b) concluded that there was a probable Inuit occupation during the second half of the 16th century. Following his analysis of the same sources, Clermont (1980) suggested that there was an Inuit occupation with very few contacts from 1560 to 1730 , followed by a gradual withdrawal to the Atlantic Coast between 1730 and 1760 . Trudel (1978a,b, 1981) asserted that there was an itinerant Inuit occupation of southern Labrador beginning approximately from 1600 to 1650 . More conservatively, Taylor (1980) suggested that there was a seasonal Inuit occupation of southern Labrador from 1700 to 1760 , followed by transient occupations starting in 1760 . As a result of the diverging interpretations, a program of archaeological research designed to shed light on the question was begun in 1983 (Auger, 1991).

Following the first exploratory fieldwork, what was originally considered to be 16th-century Inuit houses were realized in fact to be dwellings dating from a much later time period (Pastore and Auger, 1984). Moreover, it became obvious that late-18thto early-19th-century year-round European fishermen had influenced the archaeological record and that their presence had to be taken into consideration.

Therefore, after failing to find 16th-century Inuit evidence, the goal of the archaeological research was changed to the determination of the ethnic affiliation of a series of sod houses dating from the second half of the 18th century to the first quarter of the 19th century. In the study of the Labrador Inuit culture history, this is the period referred to as the "communal house phase," which is characterized by the use of large multi-family dwellings.

The objectives of this paper are to present the results of the archaeological research conducted from 1983 to 1989 and to discuss the nature of Inuit and European settlement and the ensuing Inuit/European contact and acculturation.

\section{HISTORICAL CONTEXT OF THE RESEARCH}

\section{The Inuit}

People of the ancestral Inuit Thule culture moved to the Eastern Arctic from Alaska by approximately the 11th century A.D. Their descendants began to settle in northern Labrador (Fig. 1) between 1400 and 1450 (Schledermann, 1971; Kaplan, 1983). Their southward migration along the Labrador coast undoubtedly brought them into contact with the remnant Dorset population, which occupied coastal Labrador until as late as 1500 (Thomson, 1988). It is also likely that by then Inuit met with the Point Revenge people, an Algonkian ethnic group ancestral to the present-day Innut (Montagnais) who live in Labrador ( $c f$. Fitzhugh, 1972, 1978). The presence of ancestral Innut in central Labrador may explain the lack of Labrador Inuit sites south of Nain during the 15th- to 17th-century time period (Kaplan, 1983:220).

Junius Bird (1945) published the first results of archaeological research on the Labrador Inuit. Bird's fundamental contribution proposed a three-stage development for the Inuit houses, starting with the single-family dwelling, which had one sleeping 


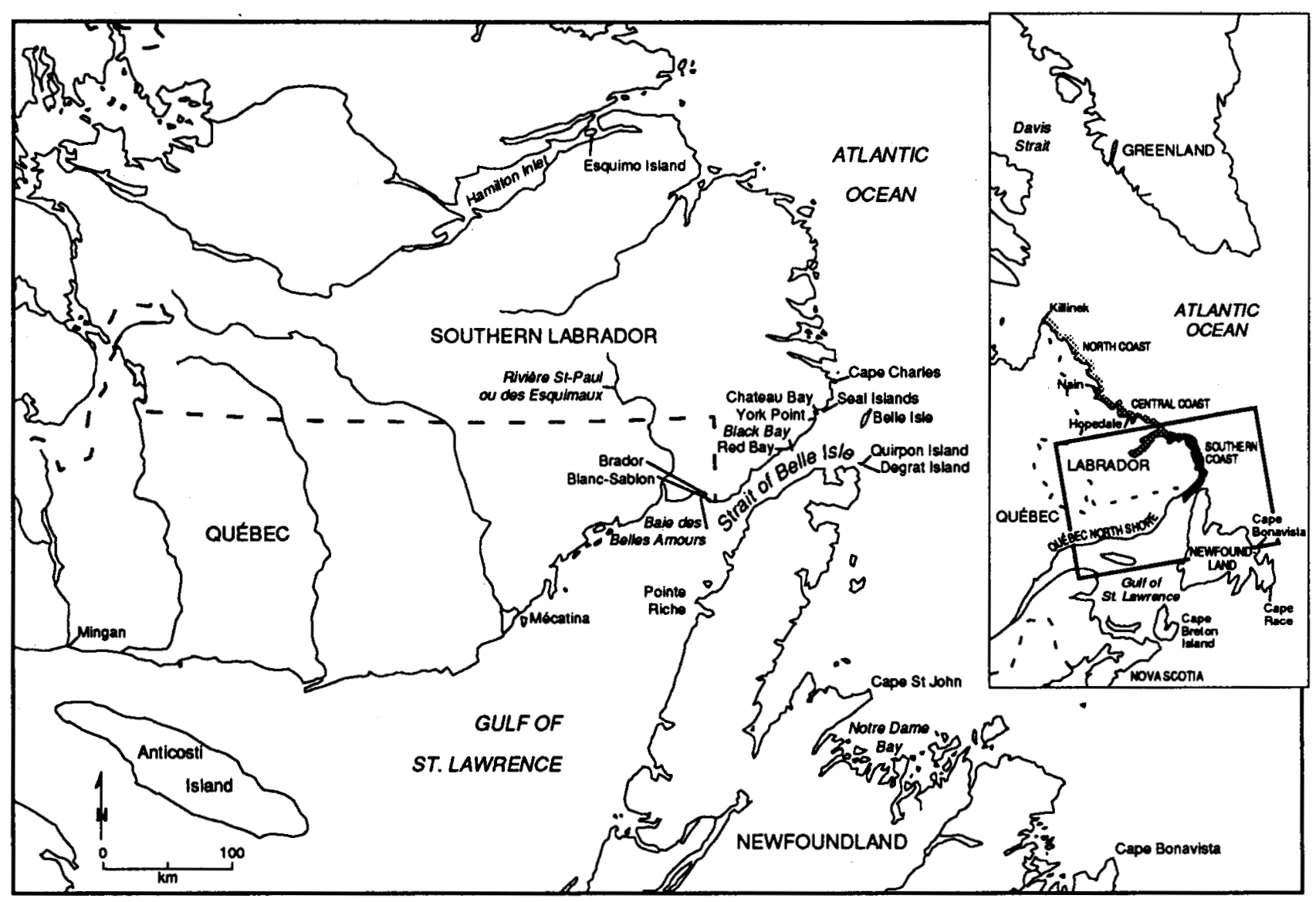

FIG. 1. Research area, Eastern Arctic, Labrador and Newfoundland (after Auger, 1991).

platform, to the type with two or three sleeping platforms and a return to the small nuclear family dwelling. He attributed these changes to an alteration of the Inuit social organization brought about by adaptation to new environmental conditions. Schledermann (1971) supported Bird's classification and postulated some dates for the changes he had identified in the Labrador Inuit culture history. In the early phase (1450-1700), the Inuit were trading with and raiding European stations, while during the second phase, "the Communal House Phase (1700-1850)," there was an increased emphasis on whale hunting and the Inuit were still in open conflict with Europeans and Innut. Finally, during the last phase (1850-present), the Inuit were fishing, trapping fur-bearing animals and selling hides for cash, as well as bartering with Europeans. He attributed the climatic change with playing an influential role in the beginning of the Communal House Phase, which furthered adjustments of the Inuit economy in a way that affected change in residential patterns.

Jordan $(1977,1978)$ excavated Labrador Inuit sod houses on Eskimo Island and suggested four chronological periods based on changes in Inuit lifeways. As such, he recognized the colonization and raiding period $(1600-1700)$, the whaling and intermittent trade period (1700-1800), the trapping and European settlement period (1800-1870) and the modern period (1870-present). Accordingly, he suggested that the appearance of the communal house form during the whaling and intermittent trade period is an adaptation resulting from the regrouping of people for cooperative whale hunts.

More recently, Kaplan $(1980,1983,1985 a, b)$ investigated the possibility that the adaptation of the communal house form might have had its roots in social and economic factors, rather than in ecological factors (Kaplan, 1983:37). She maintained that although the late-16th- and 17th-century Inuit sites from Hamilton Inlet yielded traditional material culture, the prime factor behind the Inuit expansion to Hamilton Inlet was to acquire European-made goods (Kaplan, 1985b). The beads recovered from a number of sites in that area hint of trade relations that once existed. Eighteenth-century assemblages were more diversified than the early-period assemblages (Kaplan, 1983), and the sites located closest to European establishments yielded more trade items than sites located in remoter northern Labrador.

The 19th century saw an increased diversity in the social structure and material culture of the Labrador Inuit society. There were still the large communal houses of the 18th-century style; however, the converted Inuit, under the influence of the missionaries, returned to the small nuclear family house. Bows and arrows, which had traditionally been used, were entirely replaced by firearms, but some traditional elements could not be replaced. Thus, despite the relative availability of firearms, harpoons were still in use. In sum, Inuit were in regular contact with Europeans during this period (ca. 1760-1820), and their culture was affected accordingly. Not only was the Inuit culture influenced by Europeans, but Europeans living on the Labrador coast also adopted cultural traits from Inuit (Auger, 1991).

Specific to the Strait of Belle Isle, Martijn (1974) has reported convincing evidence of an Inuit presence at the west end of the Strait of Belle Isle at the St. Paul River. From the finding of a snow knife and diagnostic skeletal remains, Martijn and 
Clermont (1980b) inferred that Inuit were present during the early contact period, which is sometime during the 17th century.

Twenty kilometres to the east of Martijn's (1974) discovery, Dumais (1985) sampled two semi-subterranean houses that yielded nails, ceramics and glass. His excavation revealed architectural traits comparable to the Labrador Inuit. While the sleeping platforms and the entrance tunnels were definitely Inuit traits, the material culture was essentially of European manufacture and suggested a late-17th- to early-18th-century occupation.

The sole archaeological evidence supporting a 16th-century Labrador Inuit presence in the Strait of Belle Isle is Tuck's (1985:232) identification of a small component in association with Basque remains at Twin Island-3 in Red Bay. The diagnostic Labrador Inuit material is a ground slate end blade and, to a lesser extent, a soapstone fragment, probably from a pot. The former is a characteristic pre-17th-century Inuit time marker (see Thomson, 1986:Plate 5).

\section{Europeans in Labrador}

Europeans have a long tradition of involvement in the northwest Atlantic fisheries. Abundant fish stocks were known to Bretons as early as the first decade of the 16th century (Turgeon, 1987 ), and their economic potential was fully recognized during the second and third decades of that century. Following the Basque exploitation of the Gulf of St. Lawrence until approximately the 1630s (Musset, 1899; Barkham, 1973, 1980; Tuck, 1985; Tuck and Grenier, 1981, 1989; Drouin, 1988; Turgeon, 1990; Turgeon et al., 1992), the Dutch began to develop trade with Inuit living on the northern Labrador coast (Kupp and Hart, 1976; Gullov, 1985). By the last quarter of the 17th century, French fishermen were on the Quebec North Shore (Gosling, 1910; Roy, 1940, 1942; Trudel, 1981), while English and Moravian missionaries followed during the second half of the 18th century in southern Labrador (Gosling, 1910; Kleivan, 1966; Zimmerly, 1975; Head, 1976; Taylor, 1980, 1984). Those mercantile seasonal occupations were followed by permanent European fishermen at the turn of the 19th century (Thornton, 1974).

French entrepreneurs began to frequent southern Labrador on a regular basis at the end of the 17th century, and their eastward expansion increased contacts with Inuit. Documents left by Jolliet (1694) described the Inuit settlements, located at the west end of the Strait of Belle Isle, which were scattered with European goods. Others tell of the trade and skirmishes between the French and Inuit during the first half of the 18th century, as well as of Inuit sailing to the south shore of the Strait of Belle Isle to acquire metal objects (see Anonymous, 1723, n.d.a, n.d.b).

By the turn of the 18th century, the coastline between Cape Race and Cape Bonavista was undisputed English fishing territory (Head, 1976:54-62). Following the signing of the Treaty of Paris in 1763, Sir Hugh Palliser, then governor of Newfoundland, took charge of the administration of Labrador and implemented a policy to develop the Labrador fisheries (Gosling, 1910). Palliser faced two obstacles - the lingering French involvement with Inuit and hostile Inuit. In 1765, in an effort to gain control over Inuit and to improve relations with them, Palliser prohibited French entrepreneurs from trading with them and announced a formal English trading policy.

The foundation of the Nain mission in 1771 marked the beginning of the first continuous contact between Labrador Inuit and Moravian missionaries, and these contacts gradually modified Inuit social structure. By regulating contacts between Christians and "heathens," "the individual was no longer free to select whom he wanted as a neighbor and partner in economic activities" (Kleivan, 1966:29). Thus, the Moravians brought about a reorganization of Inuit social organization, while strongly encouraging the traditional Labrador Inuit subsistence economy. Contacts with Moravian missionaries also provoked a considerable change in Inuit population distribution. Figures on population estimates show that for the period 1772-73 at least one-third of Labrador Inuit lived in the two southernmost Moravian posts of Hopedale and Nain, with 270 and 250 people respectively (Taylor, 1974). Among the ten remaining posts, none had a population over 160 people. Four settlements located in northernmost Labrador had 80 people or less (Taylor, 1984:513).

The most important factor, however, to account for the large number of sod houses in the Strait of Belle Isle may be the sudden influx of Newfoundland fishermen at the turn of the 19th century. Head (1976) pointed out that the saturation of the 18th-century fishing harbours around Newfoundland was the prime economic factor favouring the development of Labrador fisheries. Thornton's (1974) research on the peopling of the strait by fishermen proposed that the first permanent fishermen settlements started around the second decade of the 19th century. Prior to permanent settlements, apprentices were left to overwinter in the Strait of Belle Isle at strategic harbours in order to lay claim on them for the seasonal fishermen (Head, 1976). Unfortunately, very little is known of the role these apprentices played in keeping the shore stations. Their presence is understood in terms of economic significance for the colony, while the day-to-day life of the fishermen is left practically unreported. Questions such as where were they living and in what type of housing are left unanswered by the published sources.

\section{STUDY AREA}

The Strait of Belle Isle, located between the Island of Newfoundland and Labrador (Fig. 1), has been known to the earliest European explorers and fishermen. During his first voyage, Jacques Cartier (1968:2) referred to it as the Golfe des Châteaux, because of a peculiar rock formation at its east entrance. Toponyms such as Degrat Island and Quirpon Harbour are also mentioned regularly in 16th- and 17th-century marine guides. Seen from the water, the Strait of Belle Isle's south shore is low lying, except for the massive Cape Bauld and Cape Degrat, which have served as landmarks for early European fishermen coming to the fishing grounds off Newfoundland. The strait's north shore offers more variety in its landscape: the west end is characterized by old river deltas and protected bays, while the main feature of its east end are the harbouring facilities provided by Castle and Henley islands in Chateau Bay. That area also constitutes the southern limit of the Labrador Sea and, accordingly, is influenced by the cold Labrador current, which keeps summers colder than at the west end of the strait.

The seasonal abundance of marine resources in the Strait of Belle Isle was probably a determining factor for human occupation and from the earliest time people have lived in the strait. For European fishermen, the strait was a funnel for fish, seals and whales annually migrating between the Gulf of St. Lawrence and the Labrador Sea. 
The Degrat Island site (Fig. 2) is located at a low point of land on the channel separating Degrat Island from Quirpon Island. Two houses were identified and the house excavated at that site was at $1 \mathrm{~m}$ above sea level. The Seal Islands (Fig. 3) create a natural sheltered harbour physiographically comparable to the better known Basque harbours at Red Bay to the southwest and Pleasure Harbour to the northeast. The sod house excavated at that site was built on a storm beach $3 \mathrm{~m}$ above sea level.

\section{METHODOLOGY}

After reading the documents related to the Inuit presence in the Strait of Belle Isle, the objective of the 1983 exploratory fieldwork was aimed at recording and testing sod houses reported for the Red Bay area. Efforts were made to determine if further investigation would answer questions about the date of an Inuit presence in the strait and enable documenting the nature of that occupation (Pastore and Auger, 1984:55). The initial hypothesis was to verify Martijn's $(1980 \mathrm{a}, \mathrm{b})$ thesis that Inuit had probably lived in the strait beginning in the second half of the 16th century. However, since that hypothesis remained unsubstantiated, a new research design was proposed to investigate the ethnic affiliation of the series of late-18th- to early-19th-century sod houses located on both shores of the Strait of Belle Isle.

The 1984 research focused on the excavation of a house reported by Fitzhugh (1984) for the south shore, the sampling of another house at the same site and the survey of the strait's south shore to locate similar houses (Auger, 1985). The 1986 field research along the north shore started with an archaeological survey along the coast between Blanc Sablon and Cape Charles. After a helicopter survey to eliminate the areas with low potential, areas identified as promising for human occupation were scoured and sites that had been located from the air were sampled (Auger and Stopp, 1986, 1987). The ground was examined by two-person parties, and the locations judged habitable were shovel tested. Twelve of the 75 sites discovered yielded 21 sod houses of the type observed in 1983 and 1984.

Two houses were systematically excavated, one at Degrat Island in 1984 and the other on Seal Islands in 1986. The excavation at Degrat Island focused on the habitation as such and uncovered its entire surface. The size of the Seal Islands house precluded the excavation of more than $2 \mathrm{~m}$ wide trenches

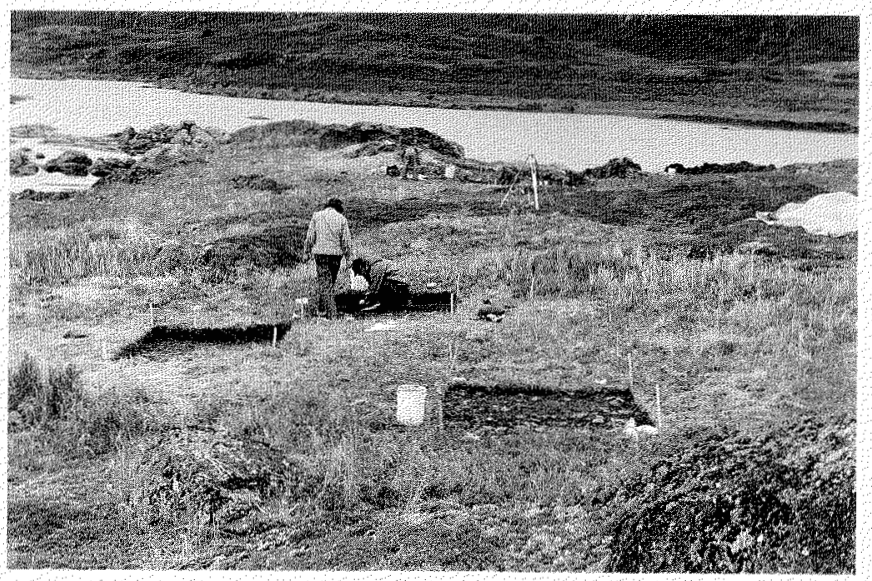

FIG. 2. Degrat Island EjAu-5 — sod house. running longitudinally and transversely, the entrance and a $2 \mathrm{~m}^{2}$ unit in its midden. Investigation at the other 21 sod houses discovered was limited to the sampling of $1 \mathrm{~m}^{2}$ in the house interiors and $1 \mathrm{~m}^{2}$ in their middens.

The case for Inuit, as opposed to European, occupation at those sod house sites was made convincingly using architectural traits in conjunction with temporal data from ceramics and smoking pipes.

\section{RESULTS}

\section{Degrat Island}

The Degrat Island house (Fig. 2) was a small, rectangular house oriented east-west with overall dimensions at the wall crests being $7 \times 5 \mathrm{~m}$. Its south wall was formed by a bedrock outcrop, and the excavation uncovered a bedrock ledge running inside the house. The floor was a series of flat stones set tightly together and covering the entire interior of the house. The building materials used in the wall construction consisted of a mixture of sod blocks and stones piled together. It was impossible to locate the doorway with certainty; it was probably indicated by a depression in the southeast corner of the house wall adjacent to the outcrop.

That house was built on top of a previous occupation, as evidenced by the material found in a level underneath it, which was a humus layer containing wood chips, seemingly resulting from barrel manufacture at the site, and a large quantity of 17th-century French artifacts. That the level was washed by high tides is suggested by water-worn smoking pipe and ceramic fragments. Based on artifact analysis, there was an approximate $130 \mathrm{yr}$ interval separating the two occupations.

\section{The Seal Islands}

The Seal Islands house (Fig. 3) was a rectangular dwelling with overall dimensions of $12 \times 6.5 \mathrm{~m}$ at the wall crests. The beach was cleared prior to its construction to create a levelled floor and the boulders taken from the centre of the house were stacked up on the walls, along with sod slabs that contained artifacts left by earlier occupants of the island. Many of its architectural traits were comparable to features associated with 18th- and 19th-century Labrador Inuit houses. The perfectly preserved sleeping platform at the rear of the house, raised by $35 \mathrm{~cm}$ above the house floor, was made of rock slabs covered

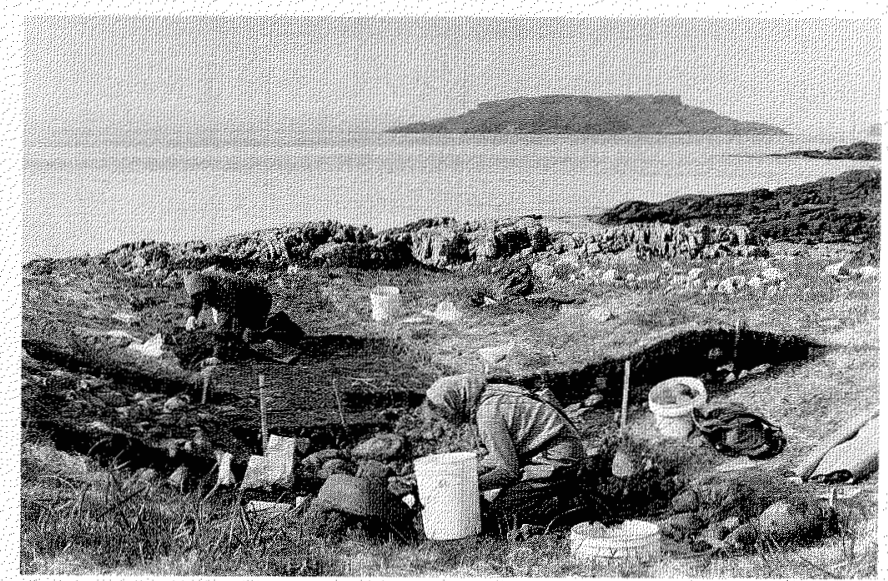

FIG. 3. Seal Islands FaAw-5 - sod house. 
with crushed shells. The walls that collapsed over the occupation were estimated to have been 1.2-1.4 m thick and approximately $1.5 \mathrm{~m}$ high. They spread over the living floor in their collapse and preserved traces of a wood plank floor and two wood sleeping platforms running parallel to the long walls. The suggestion of a plank floor and lateral sleeping platforms was indicated by decomposed wood and a rectilinear concentration of nails transversing the house, which seemingly represented the location of floor joists, while the lateral platforms were represented by decomposed wood close to the walls. There was no entrance tunnel, but a gap in the east wall of the house indicated the entrance. The poorly preserved traces of a vertical wooden post in front of the sleeping platform at the centre of the house suggested a roof support.

Excavation at the Seal Islands has uncovered evidence of at least two European occupations predating the construction of the distinct late-18th-century Labrador Inuit sod house. Some of the ceramics recovered from the house walls are of French origin and date from the first quarter of the 18th century, while the roof tiles probably represent the Basque whalers' activities whose presence in Chateau Bay has been attested for the 16th century (see Vera et al., 1986). As for the Inuit presence, the artifacts most diagnostic of that group are a traditional Labrador Inuit harpoon head (Fig. 4), a soapstone pot fragment mended with a nail and a seal tooth made into a pendant.

\section{Sod House Sites}

Efforts at the sod house sites were concentrated on gathering a sufficient collection of artifacts for inter-site comparisons, and the broadest generalization that can be made about the historical significance of their patterning is that they cluster in two groups. One group centres around Quirpon Island and the other is spread about Chateau Bay. That patterning of sod house settlements probably results from the use of the two harbours as traditional landings for European fishermen coming to fish in the Strait of Belle Isle. Architecturally the houses identified at those sites resemble the Degrat Island house and similarly lack the entrance tunnel characteristic of Inuit houses. Nevertheless, some of them have a well-defined raised sleeping platform, sod walls and an entry way. By and large, their architecture compares to what Kaplan (1983) has reported as 19th-century Inuit sod houses.

\section{DISCUSSION}

\section{Temporal Placement of the Strait of Belle Isle Sod Houses}

It is impossible to distinguish fully what constitutes the early-18th-century European component and what makes up the Inuit component at the Seal Islands. Even though the material from the house interior is analyzed separately, that assemblage probably has some artifacts that reached the house floor after its abandonment. As for Degrat Island, owing to the construction techniques used, there is always the possibility that 17th-century material is intrusive to the house, which constitutes the last occupation at the site.

The limited amount of material collected at the other sod houses precludes any in-depth discussion of their chronology. They all date from the period from the last decade of the 18th century to approximately the middle of the 19th century.

Ceramics: The Seal Islands collection is five times larger than the Degrat Island collection, and its ceramic assemblage is much more diversified; 25 types are identified for that assemblage,

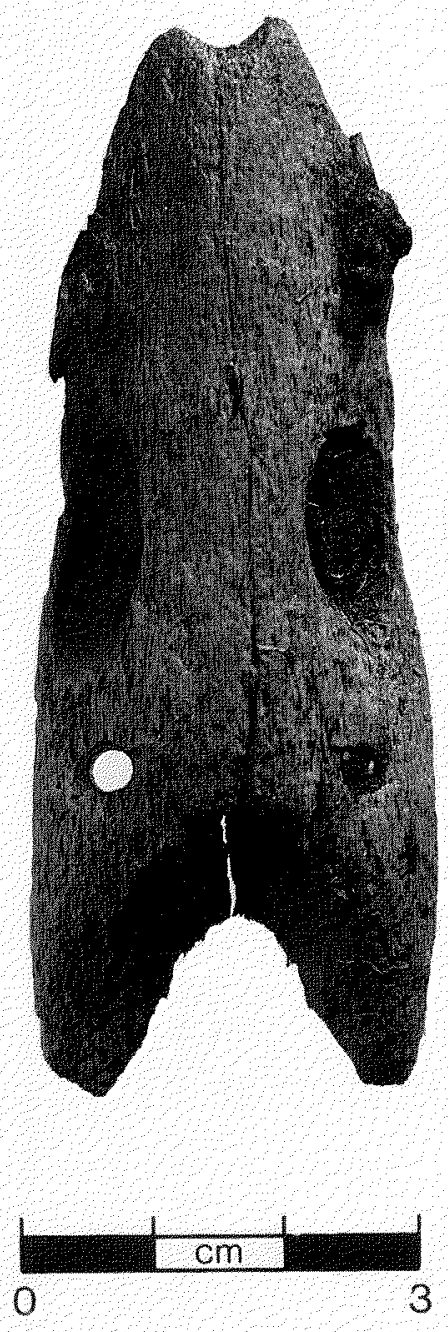

FIG 4 Seal Islands FaAw- - harpoon head with metal inset.

while 15 types are known for Degrat Island. Small tableware dominate the Seal Islands assemblage; the ceramics from Degrat Island are related to food transportation and storage, rather than to consumption.

Based essentially on the ceramics, there is a time difference of approximately two decades between the Seal Islands and the Degrat Island houses. The ceramics point to a temporal overlap with small differences between the two sites (Figs. 5, 6). A few fragments of pearlware (ca. 1800-20) are identified within the Degrat Island assemblage, which otherwise contains mostly creamware (1760-1820) as a diagnostic temporal marker. The fine earthenware at the Seal Islands is mainly of the creamware variety (1760-1820) found in association with other English stoneware of the same period or even earlier. However, the Seal Islands assemblage lacks the 19th-century fine earthenware identified at Degrat Island.

The temporal range of the Seal Islands ceramics (Fig. 5) suggests a prior hypothetical occupation dating from around the second decade of the 18th century. To verify that hypothesis, a Chi-square test was run according to four architectural features, assuming that the relationship between the artifacts and their architectural provenence was influenced by site 


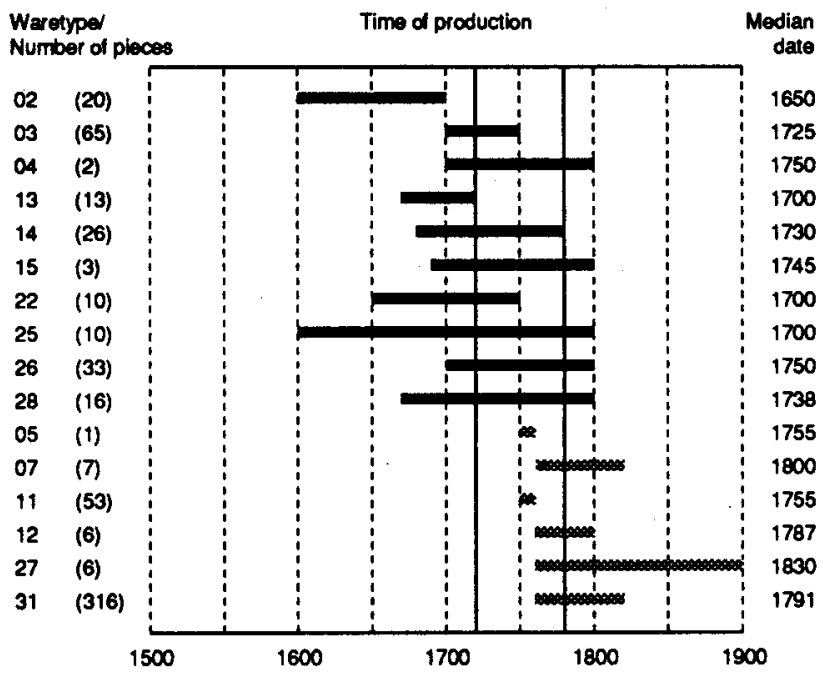

FIG. 5. Seal Islands FaAw-5 - waretypes with time of production available, median date and estimated time of occupation.

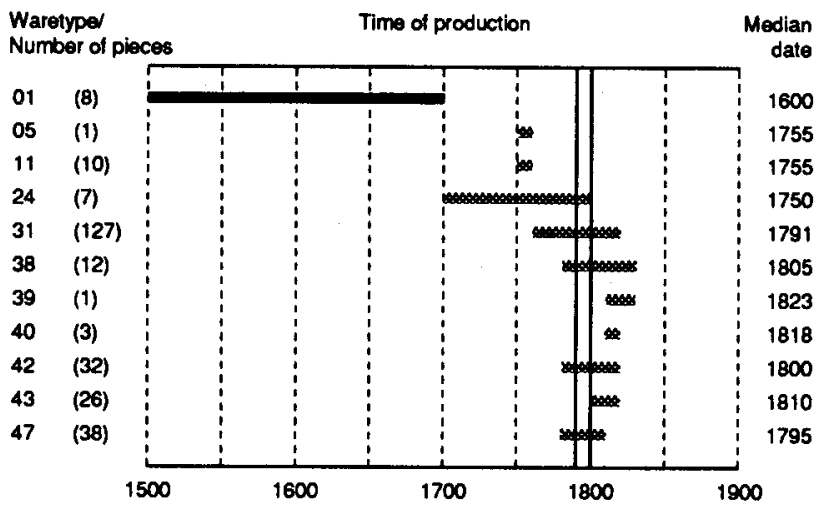

FIG. 6. Degrat Island EjAu-5 - waretypes with time of production available, median date and estimated time of occupation.

taphonomy. The features selected for the test were the house interior, the walls, the midden and the entrance. The resulting Chi-square of 142.081 (with probability level 0.01 ) suggested the possibility of at least two different groups of occupants at the Seal Islands site. Furthermore, a mean ceramic date test (South, 1977) was done according to the same ceramics respective to architectural provenences in order to verify the data obtained from the Chi-square test. The dates range from 1729.94 to 1770.16 and, surprisingly, the most recent date comes from the house walls. That late date from the walls is explained by the presence in the east wall of a large percentage of creamware $(62.33 \%)$, which has a median date of 1791 . Although somewhat more empirical, the mean ceramic date test reinforces the Chi-square test and emphasizes the proposition of two distinct periods of occupation at the Seal Islands.

Taking the Seal Islands ceramic analysis a step further, it is noted that the above range needs adjustment to account for the early ceramics coming from the first occupation (see Fig. 5). Accordingly, it is calculated that the first occupation, based on the ten ceramic types present in 1700 (198 sherds), is dated to 1719.69. The remaining six types ( 391 sherds) have a mean date of 1786.92. However, if the large number of creamware sherds recovered from the east wall is excluded, since their large number (316) skews the date abnormally, the new date for the house occupation would be 1769.76 . That suggested date is probably closer to the time of the Seal Islands occupation since it is within a decade of the date obtained from the pipe stem bore sizes, as reported below. Another reason to retain the 1769.76 date in favour of $\mathbf{1 7 8 6 . 9 2}$ is the absence of any other fine earthenware, such as pearlware which was popular during the 1770s.

For the Degrat Island assemblage, again using the mean ceramic date test on all the datable ceramic types (Fig. 6), the date would be 1787.24. Considering that the waretype 01 production period stops so much earlier than the other datable ceramics, it is eliminated from the calculations. The revised date is 1793.07. That latter date is somewhat early, considering the terminus post quem date for the smoking pipes reported below.

The assemblages from the other 21 sod houses all contain types of pearlware dated 1780-ca. 1830, whiteware ca. 1830 - present and yellowware (19th century). At the limit, they are contemporaneous with Degrat Island; however, their mean ceramic date does not indicate any contemporaneity with the Seal Islands site (see Auger, 1991).

Smoking Pipes: Lawrence's (1988) method of dating the smoking pipes according to stem bore size adds support to the interpretation of the Seal Islands ceramic data. The 244 stems from the house walls give an estimated date of 1756.10; the date for the 29 stems from the house entrance is 1756.42; and the 159 specimens from the house interior centre around 1757.18. A qualitative study of diagnostic pipe bowls (Bradley, 1989) reveals that out of 10 pipes, 9 date from the period $c a$. 1720-80 and 1 from ca. 1714-80; they are all British made. Four other specimens date from the first half of the 1700 s and they are all Dutch made.

The late date for the Degrat Island occupation prevents the use of the bore size formula to refine its dating since the post-1780 pipe manufacturers did not abide by any standard sizes. As a result, a sample was submitted to Bradley (1989) for an analysis of the pipe's qualitative attributes. His analysis (Table 1) shows further evidence of an initial occupation during the 17th century, not reported here, and modifies somewhat the date for the house occupation. Thus, while the early occupation is represented by a mixture of 17 th-century Dutch- and English-made pipes, the late specimens are essentially English made. Despite the 1793.07 date suggested by the mean ceramic date test, the late pipe specimens shift the occupation of the Degrat Island house to the beginning of the 19th century and bring it in line with the other 21 sod house sites. Such a late date can be used to account for the presence of two waretypes $(39,40)$ on Figure 6 , which date from the second decade of the 19 th century.

TABLE 1. A selection of pipes from Degrat Island

\begin{tabular}{lcl}
\hline \hline Ethnic Origin & Amount & Date \\
\hline Dutch & 1 & early 17 th century \\
English & 1 & $c a .1650-80$ \\
English & 1 & $1660-90$ \\
English & 1 & $c a .1680-1710$ \\
Dutch & 3 & $c a .1680-1710$ \\
Dutch & 1 & $c a .1680-1740$ \\
English & 1 & late 18th - early 19th century \\
English & 4 & 19 th century + \\
English & 3 & ca. 1820-1880 \\
English & 1 & 19 th century + \\
\hline
\end{tabular}




\section{Ethnic Affiliations of the Strait of Belle Isle Sod Houses}

Although they all date from a short time period, not all the sod houses discovered in the Strait of Belle Isle have been occupied by a single cultural group. Notwithstanding the mixing of the assemblages, it appears that the Seal Islands house results from an Inuit occupation, whereas the Degrat Island house, as well as the other 21 houses, seems to be of European origin. The ethnic provenience of ceramics indicates an overlap of some types between the Seal Islands and the Degrat Island assemblages, but by and large, they differ on a number of aspects.

Ceramics for which the ethnic provenience is known indicate that there is no clear-cut distinction between the Degrat Island and the Seal Islands sites. Out of 13 identifiable types at Degrat Island, 4 are French made, 8 are English made and 1 is Italian made. As for Seal Islands, out of 18 types, 4 are French made, 12 are English made, 1 is Italian made and 1 is German made. However, at both sites there is a dominance of French-made ceramics dating from the beginning of the 18th century, with a mean date of 1729 , while English ceramics dominate the second half of the 18th century with a mean date of 1781 .

The architecture of the Seal Islands house is no doubt Inuit and the diversity of its assemblage indicates non-specialized behaviour. In addition to the diversity, the large quantity of artifacts from that house is assumed to result from a number of factors. Besides the obvious mixture of two assemblages, that unusual quantity of artifacts could be an indication of the behaviour of a large Inuit household fond of European-made goods and involved in opportunistic trade with Europeans. Finally, since there is evidence of the desire by 18 th-century Labrador Inuit living in central Labrador to accumulate wealth for the purpose of trading to people from northern Labrador (see Taylor, 1974), it is likely that, whenever the Inuit came upon an abandoned European station, they scavenged whatever material they could turn into a profit.

The Degrat Island collection, which is less diversified than the Seal Islands', is seemingly a specialized settlement used by fishermen. The Degrat Island house, as well as another 21 sod houses, probably functioned as the pied-a-terre for the late-18th/early-19th-century planter fishermen who were left in the Strait of Belle Isle by the fish merchants in order to lay claim to the harbours. Their houses are concentrated at the best fishing locations and the material left at those sites shows that they survived on the bare minimum.

It is argued that the large sod house at the Seal Islands represents a late-18th-century Inuit occupation, whereas the Degrat Island house, along with the series of 21 small sod dwellings, belongs to the initial year-round European settlement of the Strait of Belle Isle. At the Seal Islands, even though the Inuit have built a house without an entrance tunnel, it is virtually identical in its architectural features to that of the 18th-century houses found at central and northern Labrador sites. As for Europeans, they have adopted a type of architecture comparable to the Inuit living at the Moravian missions. The collections from their sites are comparatively less diversified than the Inuit collections at the Seal Islands and suggest a specialization of the activities carried out at those settlements.

A limited number of inferences can be drawn about the other sod houses, which all seem to date after the 1790s. Even though they are architecturally similar to 19th-century Labrador Inuit house types, their collection patternings indicate a European origin comparable to Degrat Island. They result from the fishing activities of the initial white settlers of the Strait of Belle Isle. All the sites on the north shore but one have yielded Englishmade fine earthenware, while the sod houses located on the south shore, except for one, have yielded essentially French-made stoneware along with the usual English-made fine earthenware. The latter sites have a sufficient number of French-made Normandy stoneware to warrant the suggestion that the people living at the south shore sites have maintained an uninterrupted link with France.

In summary, the period covered (ca. 1760-1850) is of great historical complexity. Witnessed in that period was the effect of the conquest by the English, the retention of the French shore by France and the beginning of a permanent settlement of the Strait of Belle Isle by Newfoundland fishermen. Rapid acculturation of the Labrador Inuit society occurred during that time period as a result of the proximity to Europeans and economic ties strengthened by the hiring of Inuit for the fisheries. The state of intercultural acculturation between Labrador Inuit and Europeans is highlighted by the similarities in the architecture and the material culture of both groups.

\section{ACKNOWLEDGEMENTS}

I wish to acknowledge the support I received from J. Scott Raymond and Leonard V. Hills, from the University of Calgary, while working on this article. I would also like to recognize Charles A. Martijn, who read and made valuable suggestions on an early draft. I am also grateful to the three Arctic referees who made pertinent comments, and specifically to Susan A. Kaplan for clear discussions on issues of this paper. Karen M. McCullough also helped enormously with organization. Many thanks are also due to colleagues at Universite Laval, namely, Laurier Turgeon for comments while writing this article, Eileen O'Connor for her editorial suggestions and Étienne Girard, Centre d'Études Nordiques, for producing the figures.

Financial support was provided to the author by the Social Sciences and Humanities Research Council of Canada through a postdoctoral fellowship held at the Célat, Université Laval and the Faculté des Lettres at Laval through a BSR bursary.

\section{REFERENCES}

ANONYMOUS. 1723. Memoire des Exquimaux de LaBrador. Ottawa: Public Archives of Canada, MG1 A.C., Series C11A, Vol. 109:145-147. . n.d.a. Relation des Esquimaux. Ottawa: Public Archives of Canada, MG1 A.C., Series C11A, Vol. 109:101-108. n.d.b. Coste de Labrador. Ottawa: Public Archives of Canada, MG1 A.C., Series C11A, Vol. 109:467-475.

AUGER, R. 1985. The "Inuit" in the Strait of Belle Isle. In: Sproull Thomson, J., and Thomson, C., eds. Archaeology in Newfoundland and Labrador. 1983. Annual Report \#5. St. John's: Historic Resources Division, Government of Newfoundland and Labrador.

1991. Labrador Inuit and Europeans in the Strait of Belle Isle: From the written sources to the archaeological evidence. Quebec: Centre d'Études Nordiques. Collection Nordicana No. 55.

AUGER, R., and STOPP, M.P. 1986. 1986 archaeological survey of southern Labrador: Québec/Labrador border to Cape Charles. Preliminary report, ms. on file, Newfoundland Museum, St. John's.

AUGER, R., and STOPP, M.P. 1987. 1986 archaeological survey of southern Labrador: Quebec/Labrador border to Cape Charles. Final report, ms. on file, Newfoundland Museum, St. John's.

BARKHAM, S. de L. 1973. Building materials for Canada. Bulletin of the Association Preservation Technology 5(4):93-94.

1980. A note on the Strait of Belle Isle during the period of Basque contact with Indians and Inuit. Etudes/Inuit/Studies 4(1-2):51-58.

BIRD, J. 1945. Archaeology of the Hopedale area, Labrador. New York: Anthropological Papers of the American Museum of Natural History 39, Part 2. 
BRADLEY, C. 1989. Identification of smoking pipes from the Degrat Island and the Seal Islands sites. Ms. on file, Department of Archaeology, The University of Calgary, Calgary, Alberta.

CARTIER, J. 1968. Voyages de découvertes au Canada, entre les années 1534 et 1542, par Jacques Cartier, Le Sieur de Roberval, Jean Alphonse de Xanctoigne, \&c. Paris: Anthropos.

CLERMONT, N. 1980. Les Inuit du Labrador Méridional avant Cartwright. Études/Inuit/Studies 4(1-2):147-166.

DROUIN, P. 1988. Les Baleiniers Basques à l'île Nue de Mingan. Journal Canadien d'Archéologie 12:1-15.

DUMAIS, P. 1985. Evaluation du site archéologique Inuit. EiBi-12, Baie des Belles Amours. Ms. on file, Ministère des Affaires Culturelles, Gouvernement of Québec, Quebec, Quebec.

FITZHUGH, W.W. 1972. Environmental archaeology and cultural systems in Hamilton Inlet, Labrador. Washington, D.C.: Smithsonian Contributions to Anthropology 16.

1978. Winter Cove 4 and the Point Revenge occupation of the central Labrador coast. Arctic Anthropology 15(2):146-174.

. 1984. Residence pattern development in the Labrador maritime archaic: Longhouse models and 1983 field surveys. In: Sproull Thomson, J., and Thomson, C., eds. Archaeology in Newfoundland and Labrador, 1983. Report \#4. St. John's: Historic Resources Division, Government of Newfoundland and Labrador.

GOSLING, W.G. 1910. Labrador: Its discovery, exploration, and development. London: Alston Rivers, Ltd.

GULLOV, H.C. 1985. Whales, whalers, and Eskimos: The impact of European whaling on the demography and economy of Eskimo society in West Greenland. In: Fitzhugh, W., ed. Cultures in contact. Washington, D.C.: Smithsonian Institution Press. 71-96.

HEAD, C.G. 1976. Eighteenth century Newfoundland. Toronto: McClelland and Stewart.

JOLLIET, L. 1694. Journal de Louis Jolliet allant à la déscouverte de Labrador. Rapport de l'Archiviste de la Province de Québec (1943-44):149-206.

JORDAN, R.H. 1977. Inuit occupation of the central Labrador coast since 1600 A.D. In: Brice-Bennett, C., ed. Our footprints are everywhere. Nain, Labrador: Labrador Inuit Association. 43-48.

1978. Archaeological investigations of the Hamilton Inlet Labrador Eskimo: Social and economic responses to European contact. Arctic Anthropology 15(2):175-185.

KAPLAN, S.A. 1980. Neo-Eskimo occupations of the northern Labrador coast. Arctic 33(3):646-658.

1983. Economic and social change in Labrador Neo-Eskimo culture. Ph.D. dissertation, Department of Anthropology, Bryn Mawr College, Bryn Mawr, Pennsylvania.

1985a. Eskimo-European contact archaeology in Labrador, Canada. In: Dyson, S.L., ed. Comparative studies in the archaeology of colonialism. Oxford: BAR International Series 233. 53-76.

1985b. European goods and socio-economic change in early Labrador Inuit society. In: Fitzhugh, W.W., ed. Cultures in contact: The impact of European contacts on native American cultural institutions A.D. 1000-1800. Washington, D.C.: Smithsonian Institution Press. Anthropological Society of Washington Series. 45-69.

KLEIVAN, H. 1966. The Eskimos of northeast Labrador. Oslo: Norsk Polarinstitutt Skrifter Nr. 139.

KUPP, J., and HART, S. 1976. The Dutch in the Strait of Davis and Labrador during the 17th and 18th centuries. Man in the Northeast 11:3-20.

LAWRENCE, S. 1988. The PIPES program: Calculating Bindford dates on the computer. Ms. on file, Department of Archaeology, University of Calgary, Calgary, Alberta.

MARTIJN, C.A. 1974. An archaeological research on the lower St. Lawrence north shore, Québec. In: Byrne, W., ed. Archaeological salvage projects 1972. Ottawa: Mercury Series. Archaeological Survey of Canada Paper \#15. 112-130.

1980a. The "Esquimaux" in the 17th and 18th century cartography of the Gulf of St. Lawrence: A preliminary discussion. Études/Inuit/Studies 4(1-2):77-104

1980b. La Présence Inuit sur la Côte Nord du Golfe Saint-Laurent à l'Époque Historique. Études/Inuit/Studies 4(1-2):105-126.

MARTIJN, C.A., and CLERMONT, N., eds. 1980a. Les Inuit du QuébecLabrador Méridional/The Inuit of southern Québec-Labrador. Etudes/Inuit/Studies 4(1-2).
MARTIJN, C.A., and CLERMONT, N. 1980b. La Présence Inuit sur la Côte Nord du Golfe Saint-Laurent à l'Époque Historique. Études/Inuit/Studies 4(1-2):105-126.

MUSSET, G. 1899. Les Rochelais à Terre-Neuve. La Rochelle, France.

PASTORE, R.T., and AUGER, R. 1984. Archaeological investigations at Red Bay and Black Bay, Labrador. In: Sproull Thomson, J., and Thomson, C., eds. Archaeology in Newfoundland and Labrador, 1983. Report \#4. St. John's: Historic Resources Division.

ROY, P.-G. 1940. Inventaire des Pièces sur la Côte du Labrador. Québec: Archives de la Province de Québec. Vol. I.

1942. Inventaire des Pièces sur la Côte du Labrador. Québec: Archives de la Province de Québec. Vol. II

SCHLEDERMANN, P. 1971. The Thule tradition in northern Labrador. M.A. thesis, Department of Anthropology, Memorial University of Newfoundland, St. John's, Newfoundland.

SOUTH, S. 1977. Method and theory in historical archaeology. New York: Academic Press Inc.

TAYLOR, J.G. 1974. Labrador Eskimo settlements of the early contact period. Ottawa: National Museum of Man. Publications in Ethnology No. 9. 1980. The Inuit of southern Québec-Labrador. Études/Inuit/Studies 4(1-2):185-193.

1984. Historical ethnography of the Labrador coast. In: Damas, D., ed. Arctic. Vol. 5. Handbook of North American Indians. Washington, D.C.: Smithsonian Institution. 508-521.

THOMSON, C. 1988. Late Dorset shamanism at Shuldham Island 9, northern Labrador. M.A. thesis, Department of Anthropology, Bryn Mawr College, Bryn Mawr, Pennsylvania.

1986. Caribou trail archaeology: 1985 investigation of Saglek Bay and Inner Saglek Fjord. In: Thomson, C., and Sproull Thomson, J., eds. Archaeology in Newfoundland and Labrador, 1985. Annual Report \#6. St. John's: Historic Resources Division, Government of Newfoundland and Labrador. 9-53.

THORNTON, P.A. 1974. The evolution of initial permanent settlement on the Strait of Belle Isle. Unpubl. paper presented to the Harlow Seminar on Nineteenth Century Newfoundland Settlement, 27-29 May 1974. On file at Queen's Library, Memorial University of Newfoundland, St. John's.

TRUDEL, F. 1978a. L'impact des pêcheries sédentaires françaises sur les Inuit dans la région du Détroit de Belle-Isle: Un survol historique. Paper presented at the First Inuit Conference, October 1978, Laval University, Quebec.

1978b. Les Inuit du Labrador méridional face à l'exploitation canadienne et française des pêcheries (1700-1760). Revue d'Histoire de l'Amérique Française 31(4):481-499.

1981. Inuit, Amerindians and Europeans: A study of interethnic economic relations on the Canadian south-eastern seaboard (1500-1800). $\mathrm{Ph}$.D. dissertation, Department of Anthropology, University of Connecticut, Storrs, Connecticut.

TUCK, J.A. 1985. 1984 excavations at Red Bay, Labrador. In: Sproull Thomson, J., and Thomson, C., eds. Archaeology in Newfoundland and Labrador 1984. Report \#5. St. John's: Historic Resources Division, Government of Newfoundland and Labrador. 224-247.

TUCK, J.A., and GRENIER, R. 1981. A 16th century Basque whaling station in Labrador. Scientific American 245(5):180-190.

1989. Red Bay, Labrador: World whaling capital A.D. 1550-1600. St. John's: Atlantic Archaeology Ltd.

TURGEON, L. 1987. Le temps des pêches lointaines. Permanences et transformations (vers 1500 - vers 1850). In: Mollat, M., ed. Histoire des pêches maritimes en France. Toulouse: Bibliothèque Historique Privat. 133-181. 1990. Basque-Amerindian trade in the St. Lawrence during the sixteenth century: New documents, new perspectives. Man in the Northeast 40:81-89.

TURGEON, L., AUGER, R., and FITZGERALD, W. 1992. Des Basques dans le Saint-Laurent. Cap-Aux-Diamants 29:62-67.

VERA, J.A.H., CALVO, J.J.B., MARCEN, J.N., and IGARTUA, I.Z. 1986. Basque expedition to Labrador. In: Sproull Thomson, J., and Thomson, C., eds. Archaeology in Newfoundland and Labrador 1985. Report \#6. St. John's: Historic Resources Division, Government of Newfoundland and Labrador. 81-98.

ZIMMERLY, D.W. 1975. Cain's land revisited: Culture change in central Labrador, 1775-1972. St. John's: Institute of Social and Economic Research, Memorial University of Newfoundland. Newfoundland Social and Economic Studies No. 16. 